\title{
Enhancement of radiotherapy by ceria nanoparticles modified with neogambogic acid in breast cancer cells
}

This article was published in the following Dove Press journal:

International Journal of Nanomedicine

14 August 2015

Number of times this article has been viewed

\author{
Feng Chen' \\ Xiao Hong Zhang' \\ Xiao Dan $\mathrm{Hu}^{\prime}$ \\ Wei Zhang' \\ Zhi Chao Lou' \\ Li Hua Xie' \\ Pei Dang Liu² \\ Hai Qian Zhang',2 \\ 'College of Materials Science and \\ Technology, Nanjing University \\ of Aeronautics and Astronautics, \\ 2Jiangsu Laboratory for Biomaterials \\ and Devices, Southeast University, \\ Nanjing, People's Republic of China
}

Correspondence: Hai Qian Zhang College of Materials Science and Technology, Nanjing University of Aeronautics and Astronautics, Yudao street, Nanjing 21 I I00, People's Republic of China

Tel/fax +86 2552 I I 2903

Email zhanghq@nuaa.edu.cn

Pei Dang Liu

Jiangsu Laboratory for Biomaterials and Devices, Southeast University,

Dingjiaqiao, Nanjing 21 I I00, People's

Republic of China

Email seulpd@163.com

\begin{abstract}
Radiotherapy is one of the main strategies for cancer treatment but has significant challenges, such as cancer cell resistance and radiation damage to normal tissue. Radiosensitizers that selectively increase the susceptibility of cancer cells to radiation can enhance the effectiveness of radiotherapy. We report here the development of a novel radiosensitizer consisting of monodispersed ceria nanoparticles (CNPs) covered with the anticancer drug neogambogic acid (NGA-CNPs). These were used in conjunction with radiation in MCF-7 breast cancer cells, and the efficacy and mechanisms of action of this combined treatment approach were evaluated. NGA-CNPs potentiated the toxic effects of radiation, leading to a higher rate of cell death than either treatment used alone and inducing the activation of autophagy and cell cycle arrest at the G2/M phase, while pretreatment with NGA or CNPs did not improve the rate of radiation-induced cancer cells death. However, NGA-CNPs decreased both endogenous and radiation-induced reactive oxygen species formation, unlike other nanomaterials. These results suggest that the adjunctive use of NGA-CNPs can increase the effectiveness of radiotherapy in breast cancer treatment by lowering the radiation doses required to kill cancer cells and thereby minimizing collateral damage to healthy adjacent tissue.
\end{abstract}

Keywords: ceria nanoparticles, radiotherapy, breast cancer cells, neogambogic acid, radiosensitization

\section{Introduction}

Breast cancer mortality has been decreasing over the last decade owing to widespread adoption of surgery as the primary treatment option and more effective pre- and postoperative radiotherapy; nonetheless, the incidence of breast cancer is still on the rise. ${ }^{1}$ Radiotherapy plays an important role in preventing metastasis and the regeneration of tumor tissue; however, normal tissue close to the tumor is inevitably exposed to radiation during administration, especially chest and abdominal tissue moving because of respiration. ${ }^{2}$ Nanomaterials have been used in conjunction with radiotherapy in order to enhance the sensitivity of breast cancer cells to the effects of radiation and reduce damage to surrounding tissue ${ }^{3}$ some of these materials can be used for tumor-targeted drug delivery via enhancement of permeability and retention. ${ }^{4}$ Cerium oxide has various applications, including as an oxygen sensor, as an automotive catalytic converter, and as solid oxide fuel cells. ${ }^{5}$ Ceria nanoparticles (CNPs) have received considerable attention for their excellent catalytic capability derived from the rapid alteration of the oxidation state from $\mathrm{Ce}^{3+}$ to $\mathrm{Ce}^{4+} .6 \mathrm{CNPs}$ have emerged as important and lucrative materials in biological fields such as neuroprotection, radiotherapy, ocular protection, bioanalysis, biomedicine, and antioxidant therapy; ${ }^{7}$ in vitro and in vivo experiments suggest that CNPs have antioxidant and anti-inflammatory functions ${ }^{8-10}$ but can also induce lipid 
peroxidation, lung damage, reactive oxygen species (ROS) production, and autophagy. ${ }^{11}$ Other groups have previously investigated the potential of CNPs to protect normal cells against radiation-induced damage. ${ }^{12}$

Apoptosis is the main mode of radiation-induced cell death, but another important mechanism is autophagy, ${ }^{13}$ a conserved process of protein degradation in which doublemembrane vesicles known as autophagosomes engulf intracellular contents such as endoplasmic reticulum, mitochondria, and ribosomes and fuse with lysosomes for cargo degradation. ${ }^{14}$ Autophagy and consequent cell death can be induced by anticancer drugs in various types of tumor cells,${ }^{15}$ while radiotherapy stimulates both apoptosis and autophagy. ${ }^{16}$ Previous studies have shown that gamboges have therapeutic effects on breast and skin cancer and pancreatic adenocarcinoma; ${ }^{17}$ the chemotherapeutic agent neogambogic acid (NGA), an active component of gamboges, demonstrates antitumor potential in vitro and in vivo. ${ }^{18-20}$ NGA increased the death of S180-Lewis lung cancer, CNE-1 human nasopharyngeal carcinoma, and ascites carcinoma cells in a dose-dependent manner. ${ }^{21}$ In the present study, we synthesized CNPs modified with NGA (NGA-CNPs) for increased toxicity and targeting, and NGA-CNPs were tested for their ability to enhance the effectiveness of radiation in killing cancer cells. MCF-7 breast cancer cells were treated with NGA-CNPs in conjunction with radiation; the combined treatment induced cell death to a greater extent than radiation alone, and also activated autophagy and led to cell cycle arrest at the G2/M phase. Pretreatment with NGA or CNPs did not potentiate radiation-induced cell death. These results suggest that adjunctive use of NGA-CNPs can increase the effectiveness of radiotherapy in breast cancer treatment.

\section{Materials and methods Cells and reagents}

MCF-7 breast carcinoma cells were obtained from the School of Biological Science and Medical Engineering of Southeast University (Nanjing, People's Republic of China). NGA was purchased from Shanghai Shifeng Biotechnology Co. (Shanghai, People's Republic of China), and the Cyto-ID Autophagy Detection kit was purchased from Enzo Life Sciences (Plymouth Meeting, PA, USA). All other reagents were from Beyotime Institute of Biotechnology (Shanghai, People's Republic of China) or Sigma-Aldrich (St Louis, MO, USA). No ethical approval was required for this study.

\section{Synthesis and characterization of CNPs}

CNPs 3-5 nm in size were synthesized by a microemulsion method as previously described. ${ }^{22-24}$ Briefly, surfactant sodium bis(2-ethylhexyl) sulfosuccinate was dissolved in $100 \mathrm{~mL}$ toluene, followed by the addition of $5 \mathrm{~mL}$ of $0.1 \mathrm{M}$ aqueous cerium nitrate solution. The reaction mixture was stirred for 45 minutes before $10 \mathrm{~mL}$ of $1.5 \mathrm{M}$ ammonium hydroxide aqueous solution was added dropwise. The reaction proceeded for 1 hour, and the mixture was allowed to separate into two layers, with the upper layer consisting of toluene containing non-agglomerated CNPs. CNPs were washed six times with acetone and distilled water to remove the surfactant and other impurities, and size distribution and morphology were examined using a JEM-2100 highresolution transmission electron (TE) microscope (JEOL Ltd., Tokyo, Japan) equipped with an energy-dispersive analyzer by depositing drops of suspended particle solution onto a carbon-coated copper grid. ${ }^{25}$ Broad peaks in the X-ray diffraction spectrum (Ultima-3; Rigaku, Tokyo, Japan) confirmed the crystallinity of the CNPs. ${ }^{26}$

\section{Amine functionalization of CNPs}

CNPs were resuspended in $0.1 \mathrm{M}$ sodium hydroxide solution and stirred for 5 minutes before adding $2.5 \mathrm{~mL}$ distilled epichlorohydrin followed by $0.25 \mathrm{~mL}$ of $2 \mathrm{M}$ sodium hydroxide solution. The mixture was stirred at room temperature for 6-8 hours. The CNPs were then recovered by centrifugation and washed with distilled water several times until the $\mathrm{pH}$ value of the discarded water was approximately 7.0. The nanoparticles (NPs) were resuspended in distilled water, and $12.5 \mathrm{~mL}$ of $30 \%$ ammonium hydroxide solution was added followed by stirring for 14 hours. After centrifugation, the CNPs were washed with water several times and dried under vacuum..$^{27,28}$ Fourier transform infrared spectroscopy (FTIR) with a Bruker Vector-22 instrument (Bruker Daltonics, Billerica, MA, USA) was used to confirm amine functionalization.

\section{Preparation of NGA-CNPs}

NGA was dissolved in $5 \mathrm{~mL}$ dimethyl formamide (DMF) and $1.5 \mathrm{~mL}$ dichloromethane; $120 \mu \mathrm{L}$ of $N$-methyl morpholine (NMM) was then added, followed by $147.5 \mathrm{mg}$ benzotriazol1-yloxytris-(dimethyl amino) phosphonium hexafluorophosphate (BOP) reagent. The mixture was stirred for 10 minutes at room temperature before adding the amine-modified CNPs, followed by stirring for approximately 20 hours. The reaction was terminated by adding $1 \mathrm{~mL}$ distilled water. ${ }^{29}$ The particles were recovered by centrifugation and washed sequentially with DMF, acetone, and water several times to remove unconjugated NGA and other impurities. The surface functionalization of CNPs was verified by X-ray photoelectron spectroscopy (XPS) using a PHI5000 VersaProbe 
instrument (Thermo Fisher Scientific, Waltham, MA, USA). The base pressure during XPS analysis was approximately $10^{-10}$ Torr with $\mathrm{Mg} \mathrm{K}_{\alpha}$ X-radiation $(1,253.6 \mathrm{eV})$ delivered at a power of $200 \mathrm{~W}$.

\section{Cell culture and in vitro radiation}

Cells were cultured in Roswell Park Memorial Institute (RPMI) 1640 medium containing 10\% fetal bovine serum (FBS), $100 \mathrm{U} / \mathrm{mL}$ penicillin-G, and $100 \mathrm{U} / \mathrm{mL}$ streptomycin. Cells were maintained at $37^{\circ} \mathrm{C}$ in a humidified incubator with $5 \% \mathrm{CO}_{2} / 95 \%$ air. NGA, CNPs, or NGA-CNPs were dissolved in dimethyl sulfoxide (DMSO) and diluted to desired concentrations with complete culture medium. ${ }^{30}$ Control cells were treated with medium containing $<0.05 \% \mathrm{DMSO}(\mathrm{v} / \mathrm{v})$. Radiotherapy was administered in vitro using a Clinac IX $6 \mathrm{MeV}$ beam linear accelerator (Varian Medical Systems, Palo Alto, CA, USA).

\section{Clonogenic survival assay}

Radiosensitivity was evaluated with the clonogenic survival assay. ${ }^{2}$ Cells $\left(3-5 \times 10^{3}\right)$ were seeded in six-well plates. After allowing 1 day for attachment, cells were pretreated with vehicle, NGA, CNPs, or NGA-CNPs for 24 hours before exposure to radiation at doses of $0 \mathrm{~Gy}, 2 \mathrm{~Gy}, 4 \mathrm{~Gy}, 6 \mathrm{~Gy}$, or 8 Gy. After 7-10 days of culture, colonies were washed with phosphate-buffered saline (PBS) and stained with Giemsa dye, and the surviving fraction was determined by counting colonies consisting of $>50$ cells. ${ }^{31}$

\section{Determination of apoptosis and survival rates}

To assess the role of apoptosis in the cell death induced by combined treatment with NGA, CNPs, or NGA-CNPs and radiation, cells were subjected to annexin $\mathrm{V}$ /propidium iodide (PI) staining and analyzed by flow cytometry. ${ }^{32}$ Briefly, cells were trypsinized, resuspended in 10\% FBS-containing medium, centrifuged and washed twice in cold PBS, counted, and resuspended in annexin-binding buffer; $5 \mu \mathrm{L}$ annexin $\mathrm{V}$-fluorescein isothiocyanate (FITC) and $10 \mu \mathrm{L}$ PI were added to a $100 \mu \mathrm{L}$ cell suspension, and the mixture was stored in the dark for 15 minutes at room temperature. A $400 \mu \mathrm{L}$ volume of annexin-binding buffer was added to the cells, followed within 1 hour by flow cytometry analysis.

\section{Cell cycle analysis}

Cell cycle analysis was carried out by PI/RNase buffer staining as previously described. ${ }^{33}$ Briefly, treated cells were collected, fixed in $70 \%$ ethanol at $4^{\circ} \mathrm{C}$ overnight, washed with cold PBS, stained with PI/RNase staining buffer for
15 minutes in the dark, and then sorted by flow cytometry using a FACSCalibur instrument (BD Biosciences, San Jose, CA, USA).

\section{Autophagy analysis}

Cells $\left(5 \times 10^{5} /\right.$ well) were seeded on coverslips in six-well plates. After a 24-hour incubation, cells were treated with vehicle or NGA-CNPs for 24 hours at $37^{\circ} \mathrm{C}$ followed by exposure to different doses of radiation. The following day, cells were carefully washed with buffer, and dual detection reagent (prepared by diluting Hoechst 33342 nuclear stain and stock Cyto-ID green autophagy detection reagent) was applied for 20 minutes in the dark. Cells were then fixed and washed several times, ${ }^{34,35}$ and the coverslips were mounted and visualized using an Olympus FV1000 laser scanning confocal microscope (Olympus, Tokyo, Japan).

Samples were also analyzed by flow cytometry in the green (FL1) channel, which enables the visualization of the (fluorescent) autophagic fraction.

\section{Detection of ROS}

Intracellular ROS levels were determined by flow cytometry using the membrane-permeable fluorescent probe $2^{\prime}, 7^{\prime}$-dichlorofluorescin diacetate (DCFH-DA). ${ }^{36}$ Cells were seeded in six-well plates; after attachment, the cells were treated with vehicle or NGA-CNPs for 24 hours and then exposed to different doses of radiation. The cells were collected 24 hours later, washed, incubated with DCFH-DA for 30 minutes, washed with serum-free RPMI 1640, and then sorted by flow cytometry. The intracellular ROS level is represented as mean fluorescence intensity.

\section{Statistical analysis}

Data are presented as mean \pm standard deviation of at least three independent experiments and were processed with OriginPro 8.0 (Origin Lab, Northampton, MA, USA). Oneway analysis of variance and a Bonferroni test were used to analyze data. A $P$-value $<0.05$ was considered statistically significant.

\section{Results and discussion Functionalization and characterization of NGA-CNPs}

The size of CNPs synthesized by the microemulsion method ranged between $3 \mathrm{~nm}$ and $5 \mathrm{~nm}$ (Figure 1A). The selectedarea electron diffraction pattern, which indicates the crystallinity and fluorite structure of the NPs, showed lattice planes at $111,200,220$, and 311 . The TE microscopy results were supported by the X-ray diffraction pattern (Figure 1B). 
A

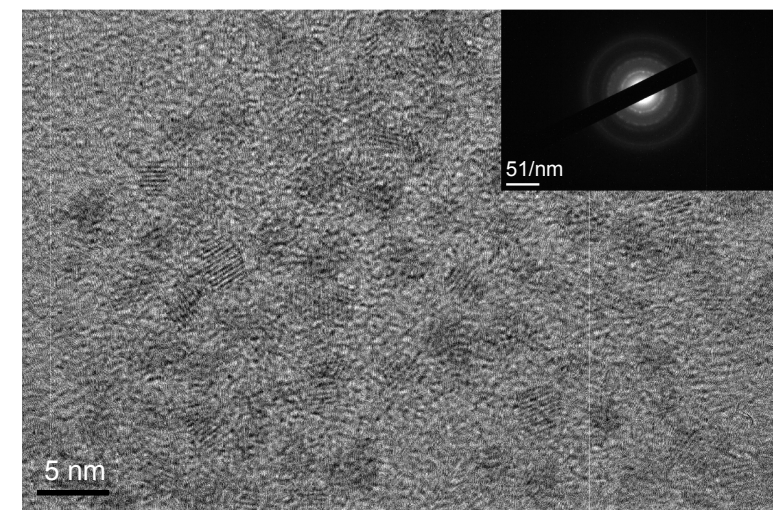

B

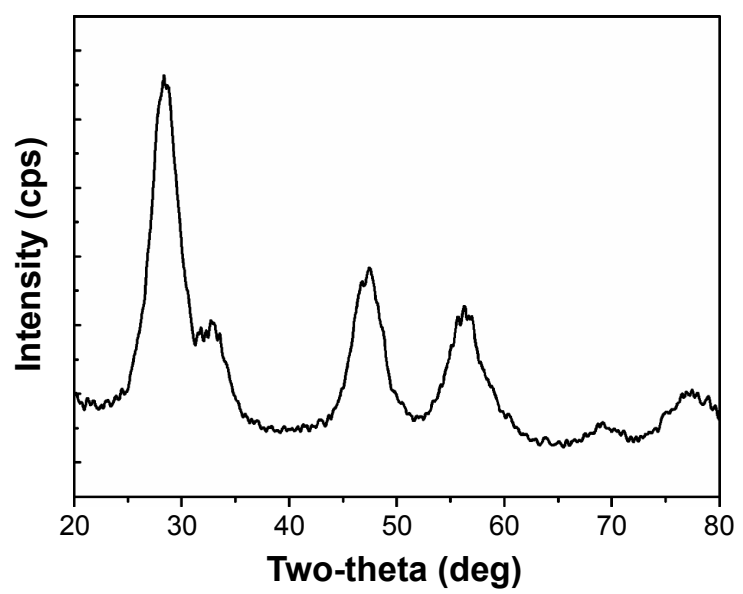

Figure I Structural analysis of CNPs.

Notes: (A) Particle size distribution (3-5 nm) of CNPs as determined by TE microscopy. The selected-area electron diffraction pattern (inset) revealed the crystallinity and fluorite structure of CNPs. (B) X-ray diffraction pattern of CNPs; III, 200, 220, and 3II correspond to the different lattice planes of the CNP crystal structure. Abbreviations: CNP, ceria nanoparticle; TE, transmission electron.

The structure of NGA and steps in the synthesis of the CNPs are shown in Figure 2. NGA was conjugated by first attaching epichlorohydrin to the NP surface via a standard $\mathrm{S}_{\mathrm{N}} 2$ reaction, in which the oxygen atom of the NP replaced the chlorine atom of epichlorohydrin, creating an oxygen bond between the NP and the carbon of epichlorohydrin. Next, ammonia was used to open up the epoxide ring of epichlorohydrin to yield hydroxyl $(-\mathrm{OH})$ and amine $\left(-\mathrm{NH}_{2}\right)$ groups available for additional reactions. The FTIR spectrum confirmed amine functionalization (Figure 3A).

The CNPs had two functional groups available for modification by NGA, which had carboxyl groups that could react with available amine groups of surface-functionalized CNPs. The coupling reaction involved the standard peptide-coupling reagents BOP and NMM, and it was carried out in DMF, a polar solvent that facilitates the reaction. The attachment of NGA to the anime groups of CNPs was confirmed by the C 1s XPS spectrum (Figure 3B), with the various peaks corresponding to different $\mathrm{C}$ positions in the NGA-CNPs.

\section{NGA-CNPs enhance radiation-induced growth inhibition}

Previous studies have documented the anticancer activities of CNPs and NGA in various tumor models. ${ }^{20,29}$ To determine whether NGA, CNPs, or NGA-CNPs increase cellular sensitivity to radiation, breast cancer cell growth upon exposure to both was evaluated with the clonogenic assay. MCF-7 cells were exposed to three different concentrations of NGA $(0 \mu \mathrm{g} / \mathrm{mL}, 0.5 \mu \mathrm{g} / \mathrm{mL}$, or $1 \mu \mathrm{g} / \mathrm{mL})$, CNP $(0 \mu \mathrm{g} / \mathrm{mL}$, $10 \mu \mathrm{g} / \mathrm{mL}$, or $20 \mu \mathrm{g} / \mathrm{mL})$, or NGA-CNP $(0 \mu \mathrm{g} / \mathrm{mL}, 10 \mu \mathrm{g} / \mathrm{mL}$,

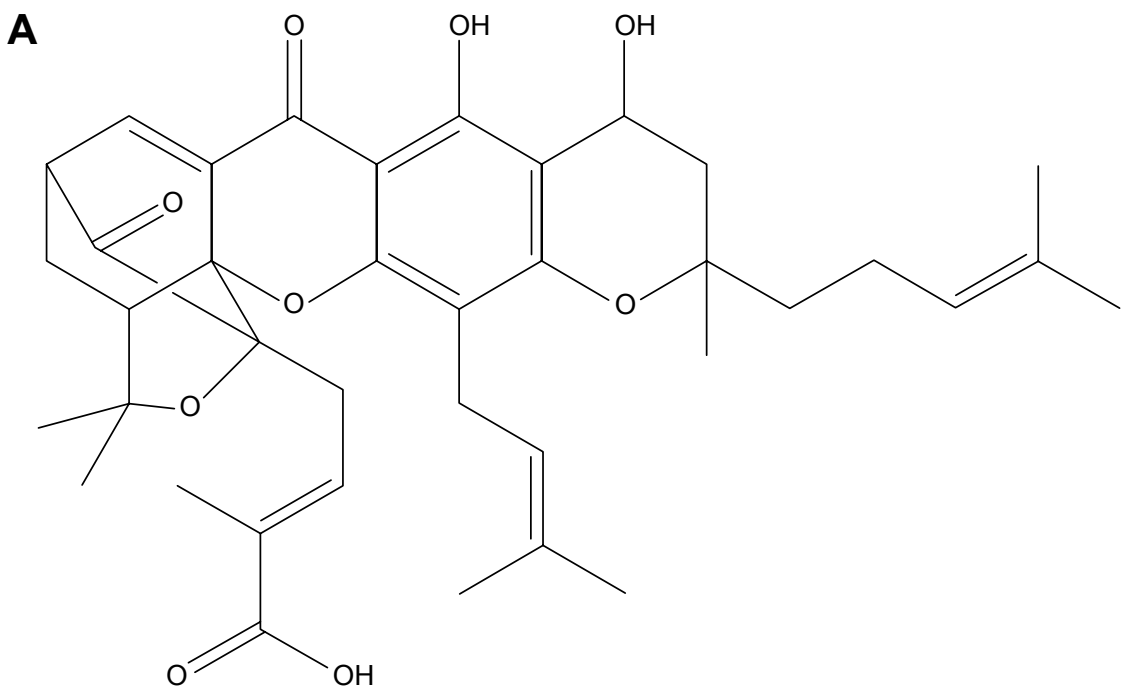

Figure 2 (Continued) 
B
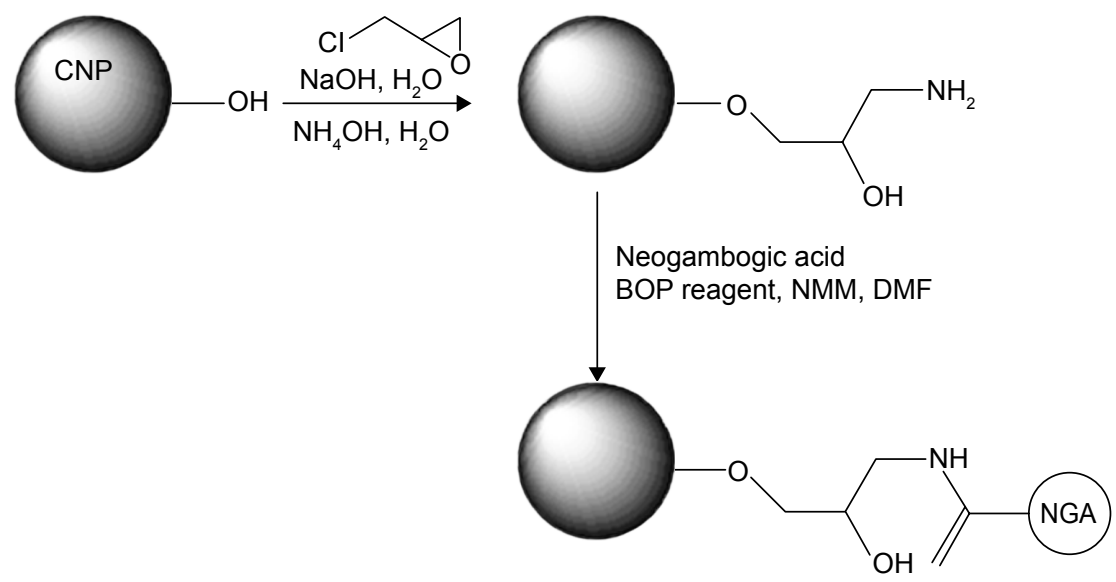

Figure 2 NGA-CNP synthesis.

Notes: (A) Structure of NGA. (B) Steps in the synthesis of NGA-CNPs.

Abbreviations: NGA-CNP, ceria nanoparticle modified with neogambogic acid; NGA, neogambogic acid; CNP, ceria nanoparticle; BOP, benzotriazol-I-yloxytris-(dimethyl amino) phosphonium hexafluorophosphate; NMM, N-methyl morpholine; DMF, dimethyl formamide.

or $20 \mu \mathrm{g} / \mathrm{mL}$ ) for 24 hours prior to irradiation at one of five doses (0 Gy, 2 Gy, 4 Gy, 6 Gy, or 8 Gy). The doses of NGA were the same as those used for the synthesis of NGA-CNP. Exposure to $4 \mathrm{~Gy}$ radiation decreased the colony formation rate to $49.03 \%$. However, at $0.5 \mu \mathrm{g} / \mathrm{mL}$ and $1 \mu \mathrm{g} / \mathrm{mL}$ NGA, colony formation was reduced to $37.01 \%$ and $34.89 \%$, respectively ( $P<0.05$ vs 4 Gy radiation only); at $10 \mu \mathrm{g} / \mathrm{mL}$ and $20 \mu \mathrm{g} / \mathrm{mL} \mathrm{CNP}$, colony formation was reduced to $46.32 \%$ and $35.27 \%$, respectively; and at $10 \mu \mathrm{g} / \mathrm{mL}$ and $20 \mu \mathrm{g} / \mathrm{mL}$ NGACNP, colony formation was reduced to $40.69 \%$ and $31.97 \%$, respectively ( $P<0.05$ vs 4 Gy radiation only) (Figure 4$)$. The inhibitory effects of other doses of radiation on colony formation were likewise enhanced by combined treatment with
NGA-CNPs, which reduced the colony-forming efficiency of cancer cells to a greater extent than NGA or CNP, suggesting that NGA-CNPs sensitize cells to the effects of radiation.

\section{NGA-CNPs enhance radiation-induced cell death}

To determine the rate of apoptosis and cell mortality following combined treatment with NGA/CNPs/NGA-CNPs and radiation, cells were analyzed by annexin V/PI staining and flow cytometry. Annexin V-FITC is used as a nonquantitative probe to detect cell surface expression of phosphatidylserine, an early marker for apoptosis. ${ }^{37}$ PI permeates cells with a damaged cell membrane and is therefore used to identify
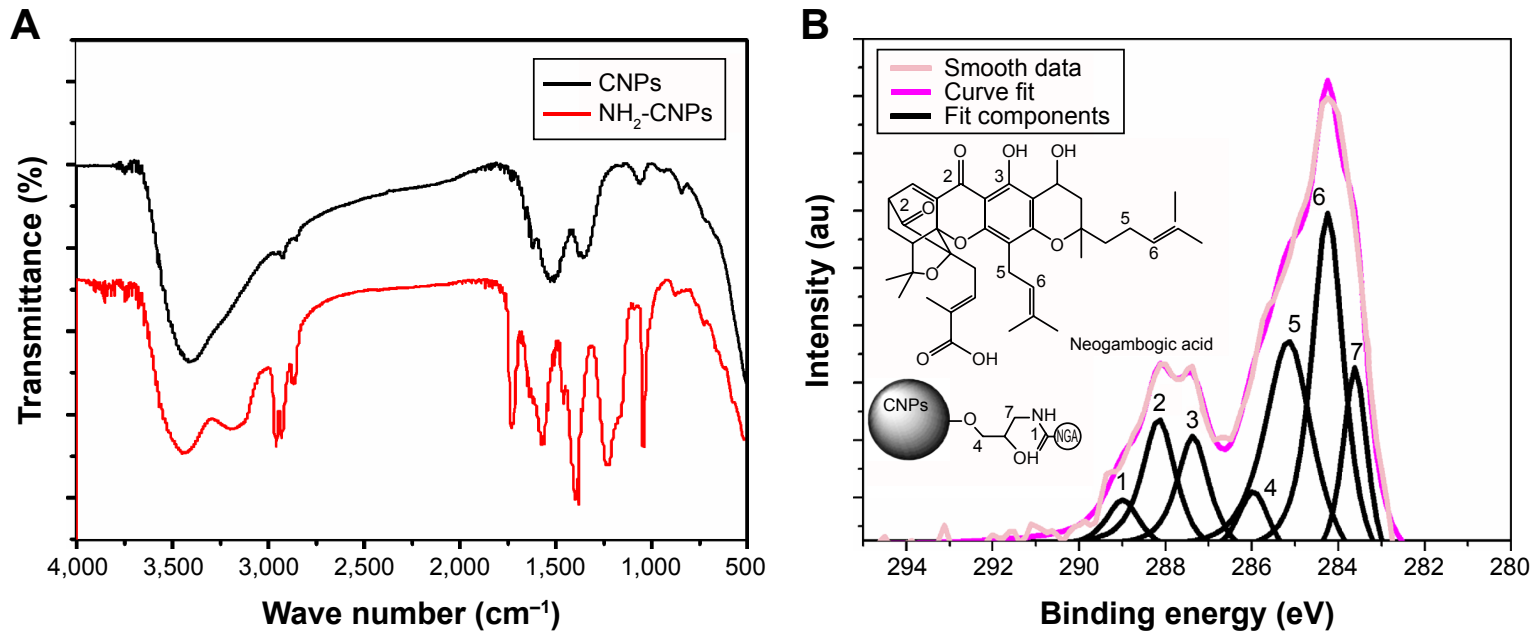

Figure 3 FTIR and XPS analysis of NGA-CNPs.

Notes: (A) FTIR spectrum of CNPs before and after modification with epichlorohydrin. Absorption at I, I00 $\mathrm{cm}^{-1}$ and I,650 $\mathrm{cm}^{-1} \mathrm{corresponding}$ to hydroxide and amine groups, respectively, was observed for amine-functionalized $\mathrm{CNPs}\left(\mathrm{NH}_{2}-\mathrm{CNP}\right.$; red line) relative to unmodified CNPs (black line). (B) XPS spectrum of functionalized CNPs. Numbers represent positions of peaks.

Abbreviations: FTIR, Fourier transform infrared spectroscopy; XPS, X-ray photoelectron spectroscopy; NGA-CNP, ceria nanoparticle modified with neogambogic acid; CNP, ceria nanoparticle; au, arbitrary unit. 

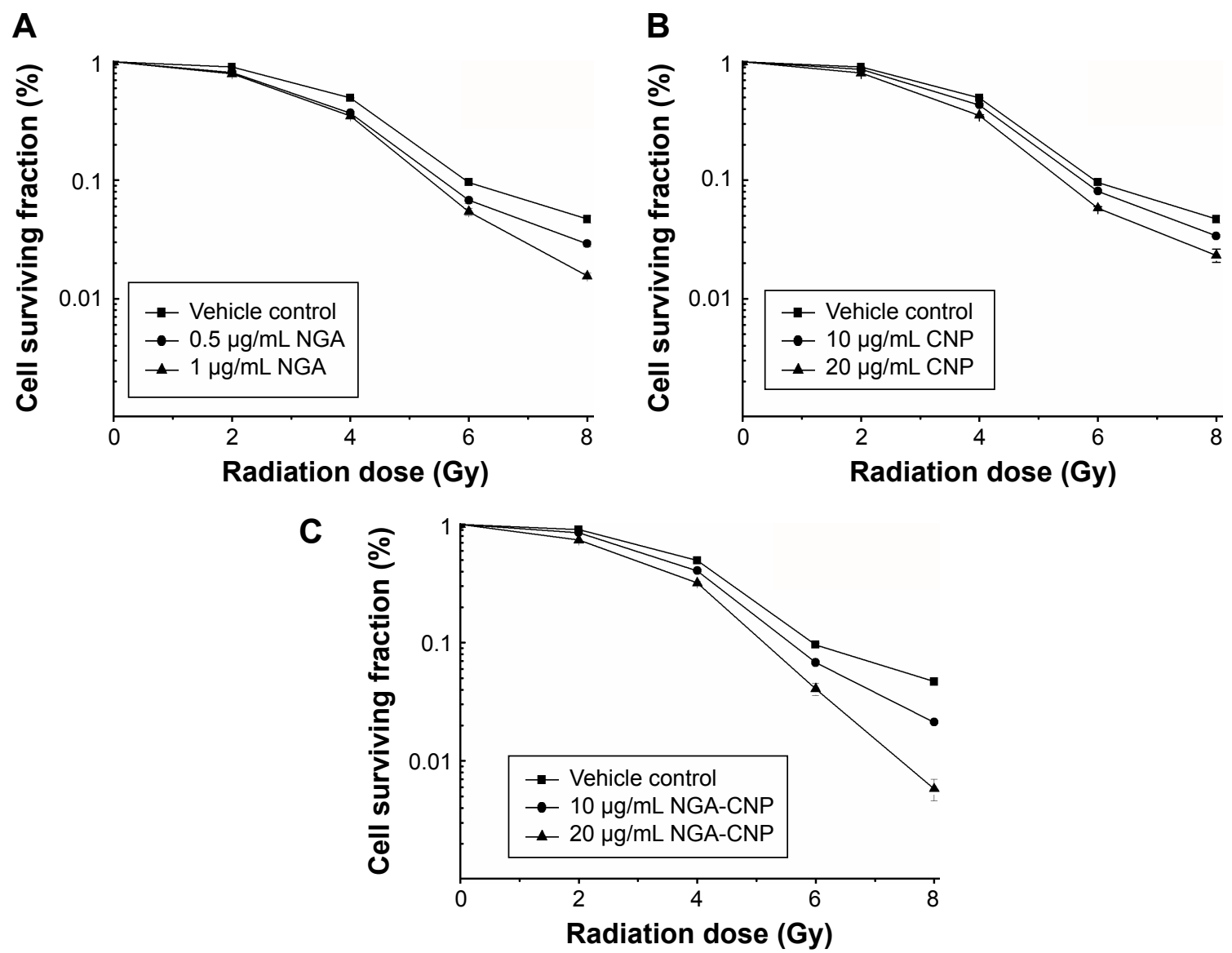

Figure 4 Enhancement of radiation-induced growth inhibition by NGA, CNP, and NGA-CNPs.

Notes: The surviving fraction of MCF-7 cells was decreased by RT in a dose-dependent manner, an effect that was potentiated by the addition of NGA-CNPs. (C), compared with NGA (A), or CNPs (B).

Abbreviations: NGA, neogambogic acid; CNP, ceria nanoparticle; NGA-CNP, ceria nanoparticle modified with neogambogic acid; RT, irradiation.

apoptotic or necrotic cells. ${ }^{37}$ Pretreatment of cells with NGACNPs and radiation inhibited proliferation to a greater degree than radiation alone or combined NGA and radiation treatment, while pretreatment with CNPs and radiation-induced cell death to an extent similar to radiation alone (Figure 5). Radiation delivered at a dose of 6 Gy or treatment with $0.5 \mu \mathrm{g} / \mathrm{mL}$ NGA, $10 \mu \mathrm{g} / \mathrm{mL}$ CNP, or $10 \mu \mathrm{g} / \mathrm{mL}$ NGA-CNP induced death in $17.40 \%, 11.14 \%, 7.63 \%$, and $8.13 \%$ of cells, respectively. However, $10 \mu \mathrm{g} / \mathrm{mL}$ NGA-CNPs combined with 6 Gy radiation increased cell death to $29.26 \%$ (percent apoptosis: $11.49 \%)(P<0.001$ vs 6 Gy radiation only), while NGA or CNPs combined with radiation increased cell death only to $21.04 \%$ (percent apoptosis: $5.02 \%$ ) and $18.73 \%$ (percent apoptosis: $9.09 \%$ ), respectively. When an NGA-CNP concentration of $20 \mu \mathrm{g} / \mathrm{mL}$ was used in conjunction with 6 Gy radiation, the rate of cell death was $34.65 \%$ (percent apoptosis: $8.24 \%)(P<0.001$ vs 6 Gy radiation only), whereas treatment with $20 \mu \mathrm{g} / \mathrm{mL}$ NGA-CNP alone did not increase cell death. These results confirm that NGA-CNP potentiates the radiation-induced death of cancer cells to a greater extent than NGA or CNP alone and is far less toxic than NGA, and can therefore reduce damage to surrounding tissue in radiation therapy. In subsequent experiments, we investigated the mechanism underlying the sensitization of cells to the effects of radiation by NGA-CNP.

\section{NGA-CNPs enhance radiation-induced G2/M arrest}

To clarify the mechanism by which NGA-CNPs enhance cancer cell sensitivity to radiation, we examined the effects of combined treatment on cell cycle regulation by flow cytometry. Treatment with NGA-CNPs and radiation decreased the fraction of cells in $\mathrm{G} 0 / \mathrm{G} 1$ phase and increased the fraction in G2/M phase as compared to untreated control cells (Figure 6). For instance, $4.57 \%$ of control cells were in $\mathrm{G} 2 / \mathrm{M}$ phase; NGACNP treatment at concentrations of $10 \mu \mathrm{g} / \mathrm{mL}$ and $20 \mu \mathrm{g} / \mathrm{mL}$ increased the $\mathrm{G} 2 / \mathrm{M}$ fraction to $4.89 \%$ and $6.44 \%$, respectively; these values increased to $17.39 \%$ and $18.03 \%$, respectively ( $P<0.05$ vs 6 Gy radiation only), when NGA-CNPs were combined with $6 \mathrm{~Gy}$ radiation. These results indicate that simultaneous exposure of cells to NGA-CNPs and radiation causes acceleration through G1/S and arrest in G2/M phase. 

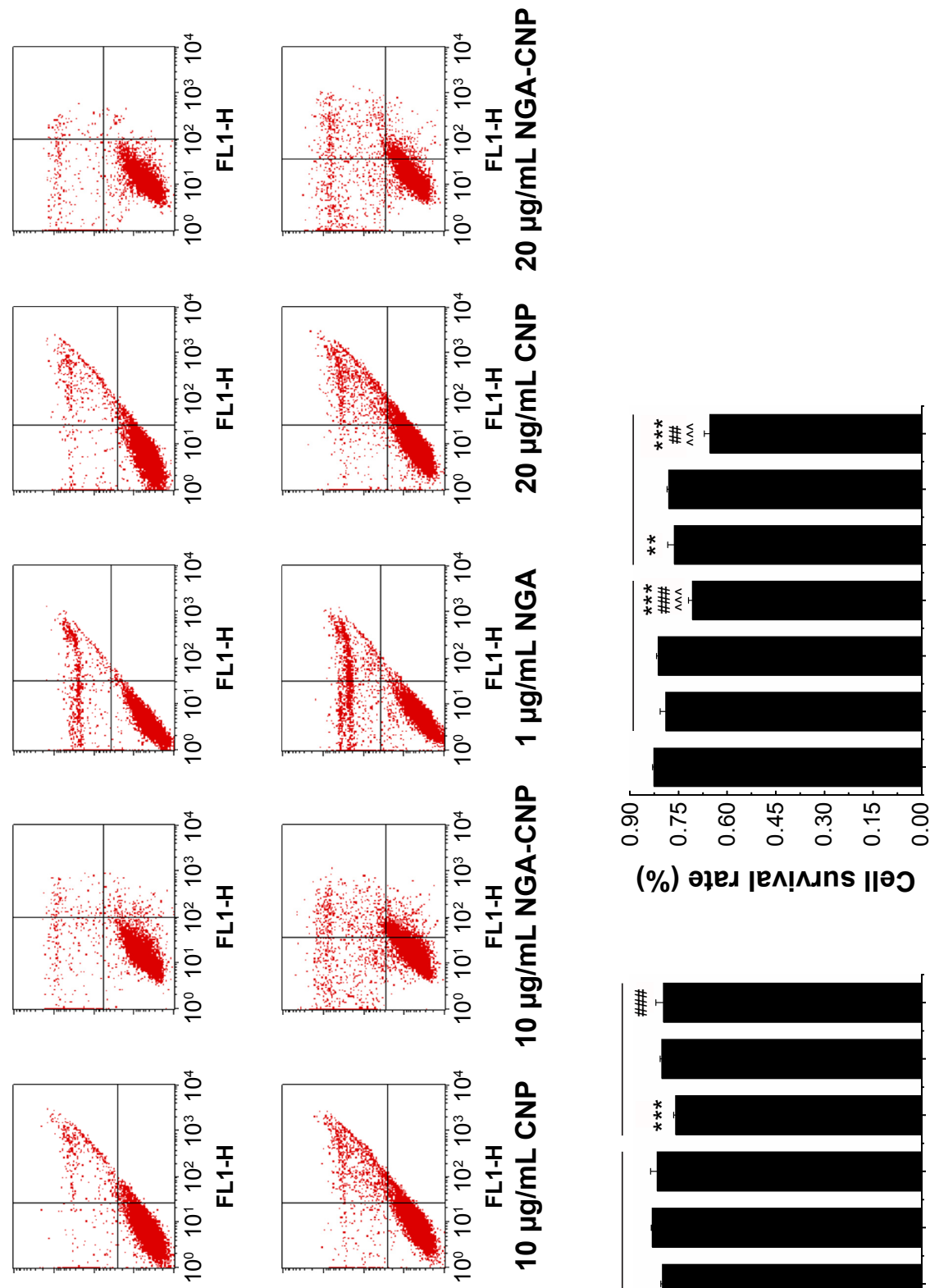

(\%) әұеג ןen!ıuns ||ә弓

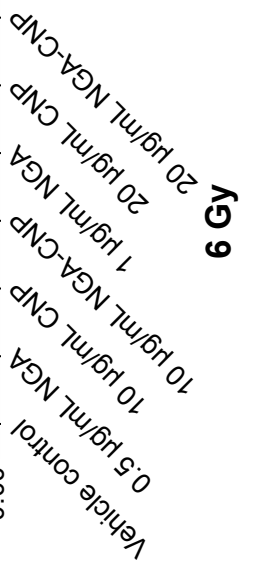

돓

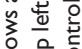

的 8

离

递茫紊

产

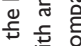

음

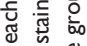

드은

畜

뒁ㅇㅇㅇ

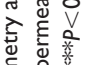

产造

举 हैं

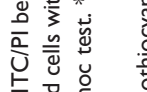

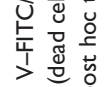

突

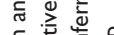

专语产

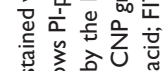

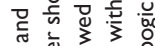

岳

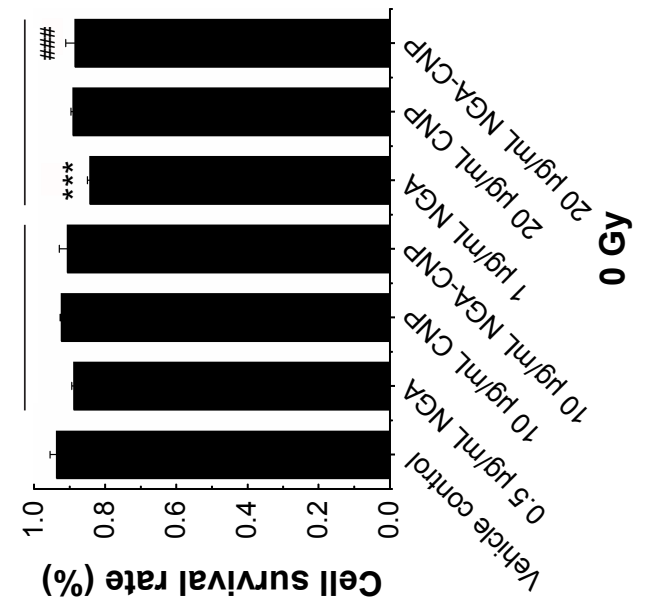

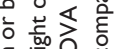

든

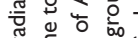

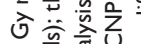

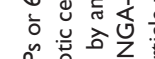

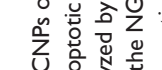

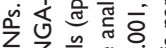

Z Z

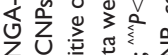

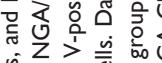

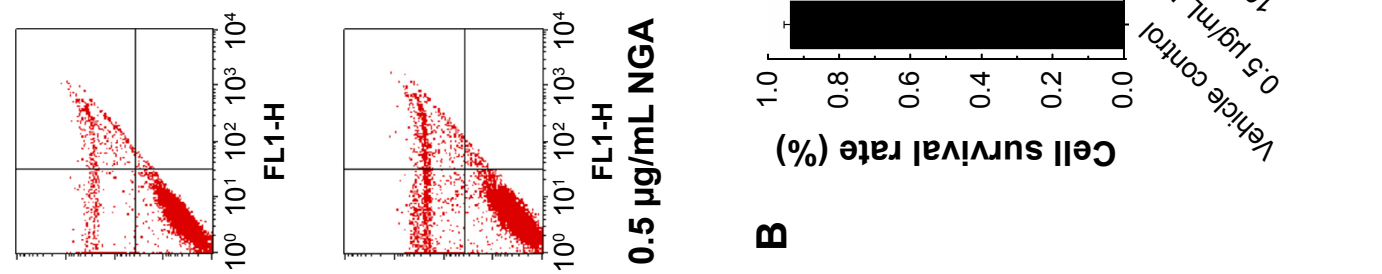

至

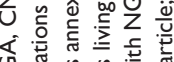

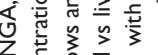

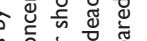

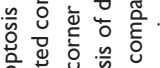

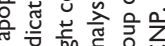

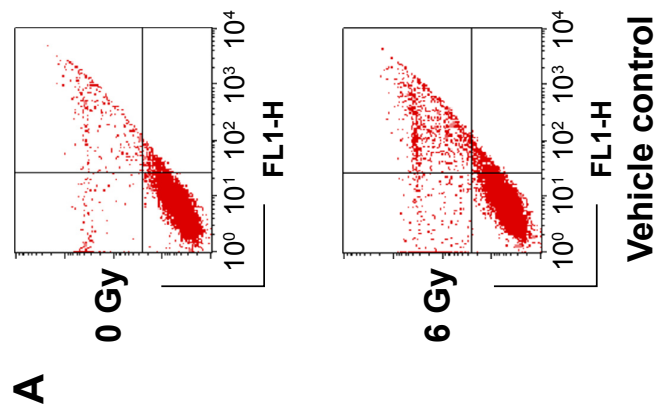

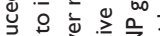

势

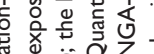

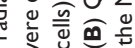

$\div 3$ bo.

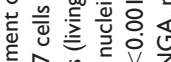

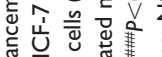

运 $\Sigma$ 造

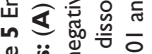

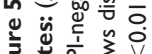

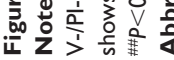


A
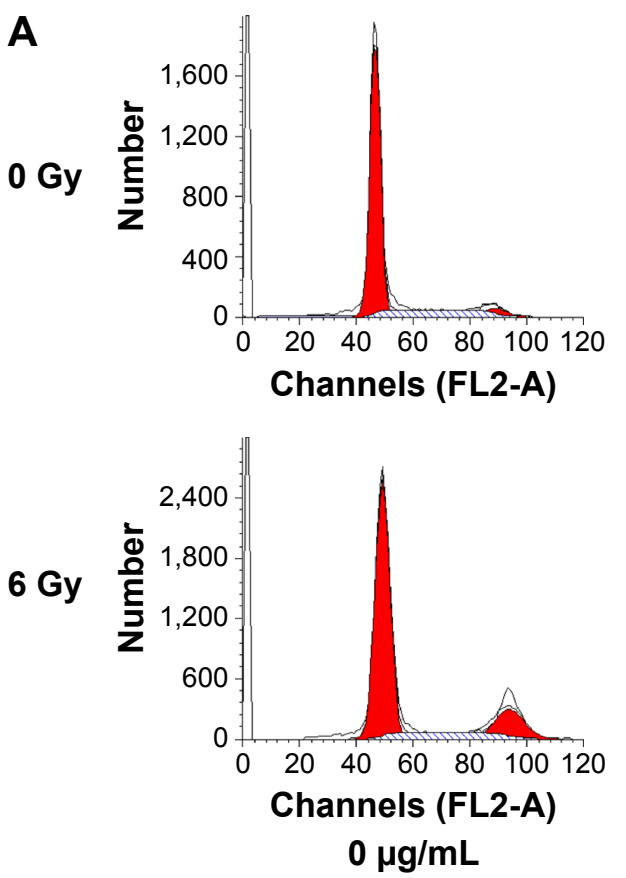
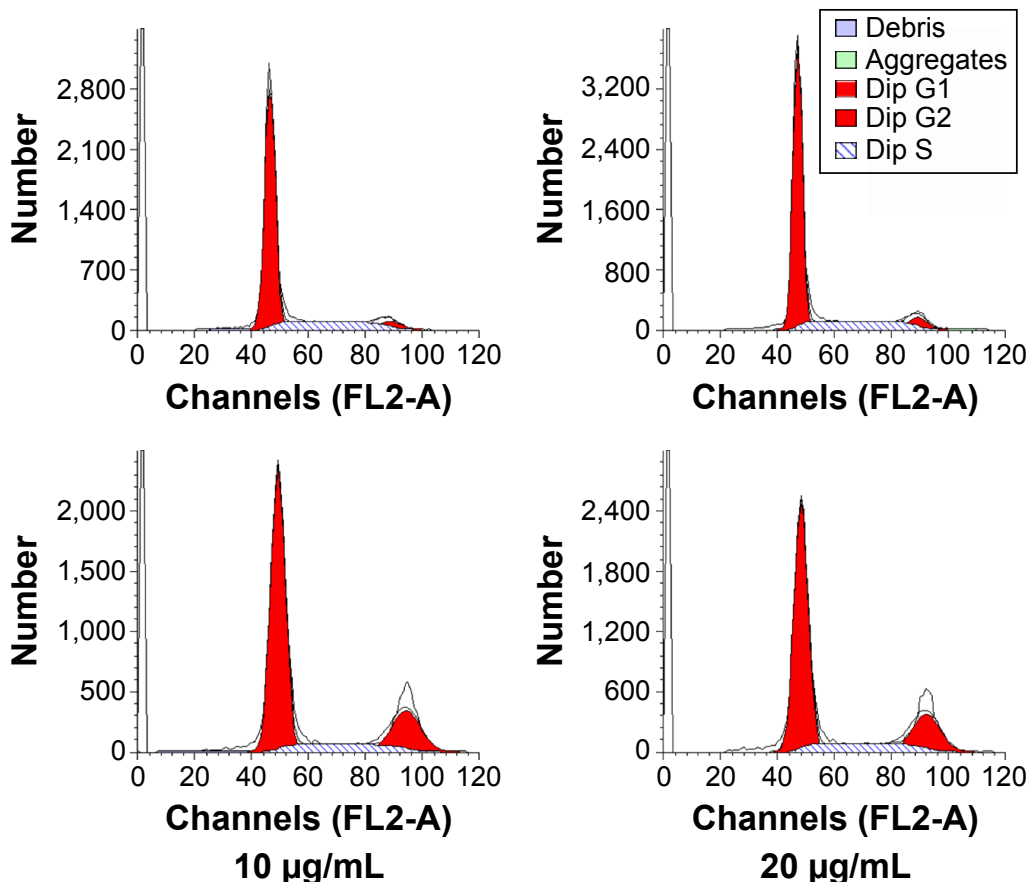

B

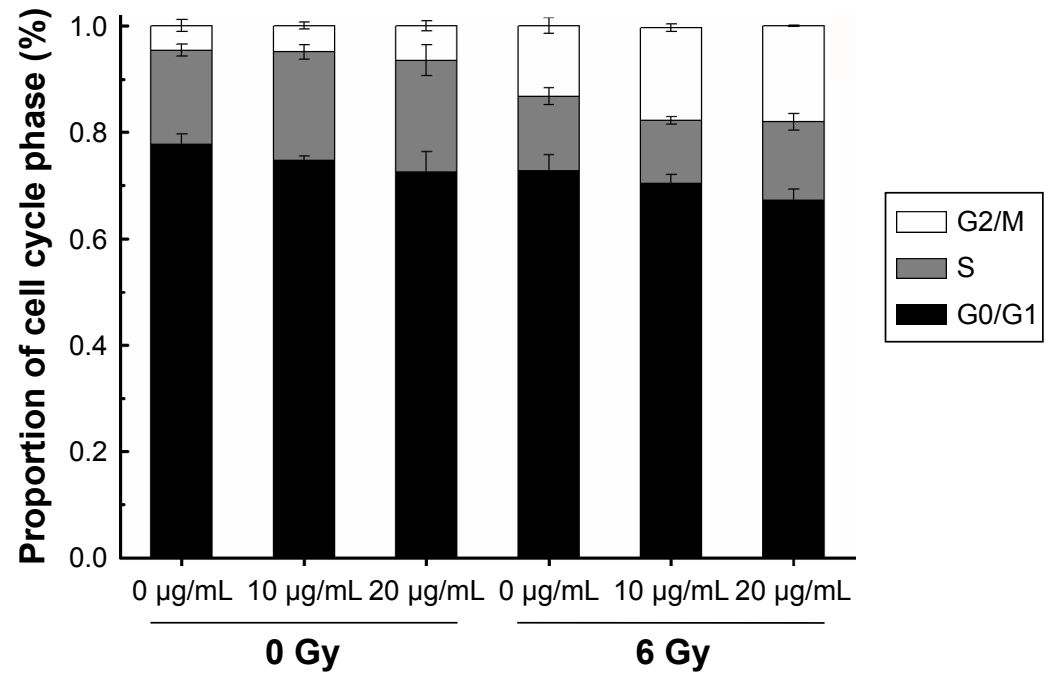

Figure 6 Effect of NGA-CNPs on MCF-7 cell cycle distribution.

Notes: (A) Cells were pretreated with the vehicle DMSO or NGA-CNPs for 24 hours before exposure to 0 Gy or 6 Gy radiation, and the fraction of cells in each phase of the cell cycle was analyzed by flow cytometry. (B) Quantitative analysis of cell cycle distribution.

Abbreviations: NGA-CNP, ceria nanoparticle modified with neogambogic acid; DMSO, dimethyl sulfoxide; G2, second gap phase; M, mitosis phase; S, synthesis phase; $\mathrm{G} 0$, zero gap phase; GI, first gap phase.

Since cells are most sensitive to the effects of radiation in the latter phase and most resistant in $\mathrm{G} 0 / \mathrm{G} 1,{ }^{33}$ one potential mechanism by which NGA-CNPs enhance the effects of radiotherapy is by regulating cell cycle progression.

\section{Combined NGA-CNP and radiation treatment induces autophagy}

Recent reports suggest that radiation and some anticancer drugs exert their effects by inducing autophagy, and consequently, tumor cell death. ${ }^{38-48}$ Autophagic activity is typically low under basal conditions but can be upregulated by endogenous and external signals such as nutrient starvation, energy depletion, radiation, and invasion by pathogens. ${ }^{49,50}$ Autophagy can be detected by TE microscopy or other methods that allow the visualization of autophagosome accumulation in the cytoplasm. ${ }^{13}$ To determine whether autophagy was induced by combined NGA-CNP and radiation treatment, we used a commercial autophagy detection kit that employs the green fluorescent probe Cyto-ID to label vacuolar components of the autophagy pathway. It should be noted that unlike lysosomotrophic dyes such as acridine orange, monodansylcadaverine, and LysoTracker Red, which 
primarily detect lysosomes, the Cyto-ID only weakly stains lysosomes and serves as a selective marker of autolysosomes and earlier autophagic compartments.

Cells were incubated with NGA-CNPs for 24 hours, exposed to 6 Gy radiation, and then labeled with Cyto-ID as well as Hoechst 33342 to detect nuclei. Quantitative analysis of autophagic cells is shown in Figure 7. Cells containing at least three green dots or a green cluster corresponding to microtubule-associated light chain protein 3 (LC3) puncta were determined as autophagic cells; at least 150 cells were counted in triplicate samples. ${ }^{15}$ Exposure to radiation or
$10 \mu \mathrm{g} / \mathrm{mL}$ or $20 \mu \mathrm{g} / \mathrm{mL}$ NGA-CNPs alone did not lead to the obvious formation of LC3-positive puncta in confocal images (Figure 7). However, a combination of NGA-CNP and 6 Gy radiation increased the number of LC3-positive puncta relative to those treated with radiation alone $(P<0.001$ vs 6 Gy radiation only). These results were confirmed by flow cytometry and suggest that the enhancement of autophagy is a mechanism by which NGA-CNPs sensitize cancer cells to the effects of radiation (Figure 8). However, additional studies are needed to determine the relationship between the induction of autophagy and the increased rate of cell death.
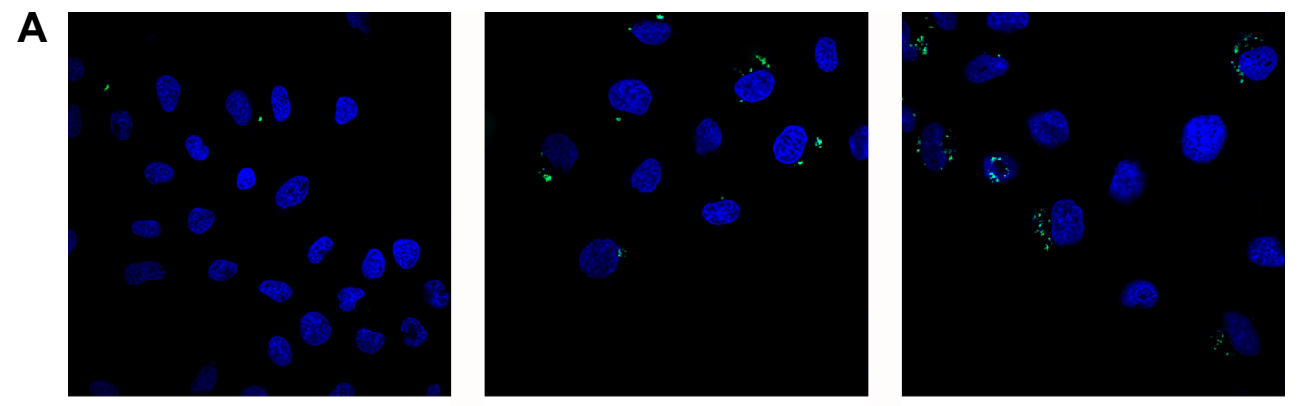

0 Gy

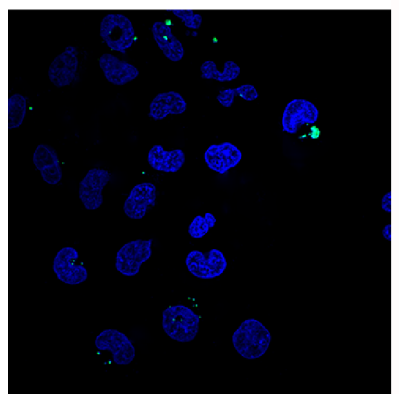

$0 \mu \mathrm{g} / \mathrm{mL}$

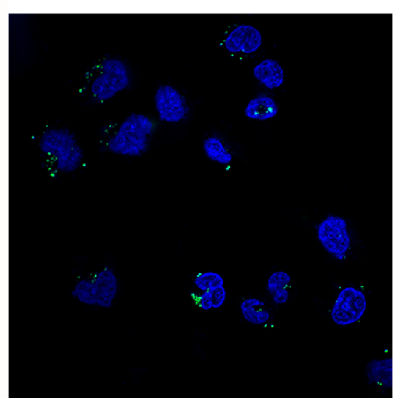

$10 \mu \mathrm{g} / \mathrm{mL}$

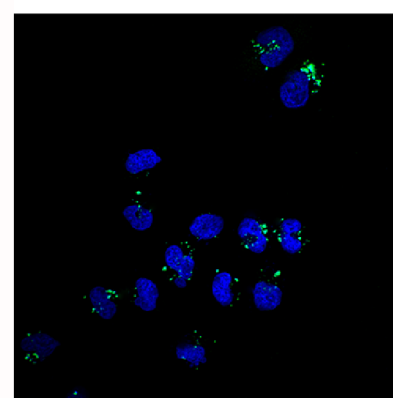

$20 \mu \mathrm{g} / \mathrm{mL}$

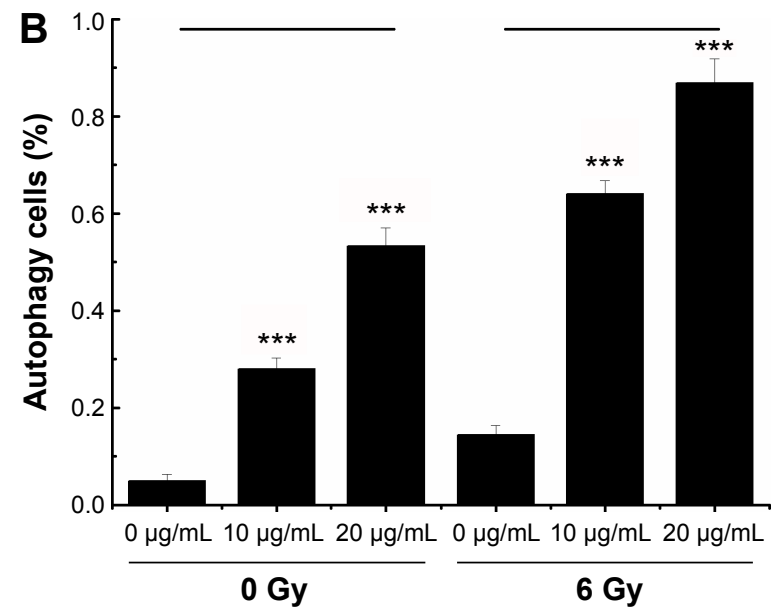

Figure 7 Autophagy in MCF-7 cells treated with NGA-CNPs and radiation.

Notes: (A) Cells were incubated with indicated concentrations of NGA-CNPs for 24 hours followed by exposure to indicated doses of radiation; 24 hours later, cells were stained Cyto-ID (green) for detection of autophagic vacuoles and counterstained with Hoechst 33342 to label nuclei. (B) Quantitative analysis of autophagic cells (ie, with at least three green dots or a green cluster). Data were analyzed by analysis of ANOVA followed by Bonferroni post hoc test. $* * * P<0.000 \mathrm{I}$, the groups compared with vehicle control groups ( $0 \mu \mathrm{g} / \mathrm{mL}+0$ Gy group, or $0 \mu \mathrm{g} / \mathrm{mL}+6$ Gy group).

Abbreviations: NGA-CNP, ceria nanoparticle modified with neogambogic acid; ANOVA, analysis of variance. 

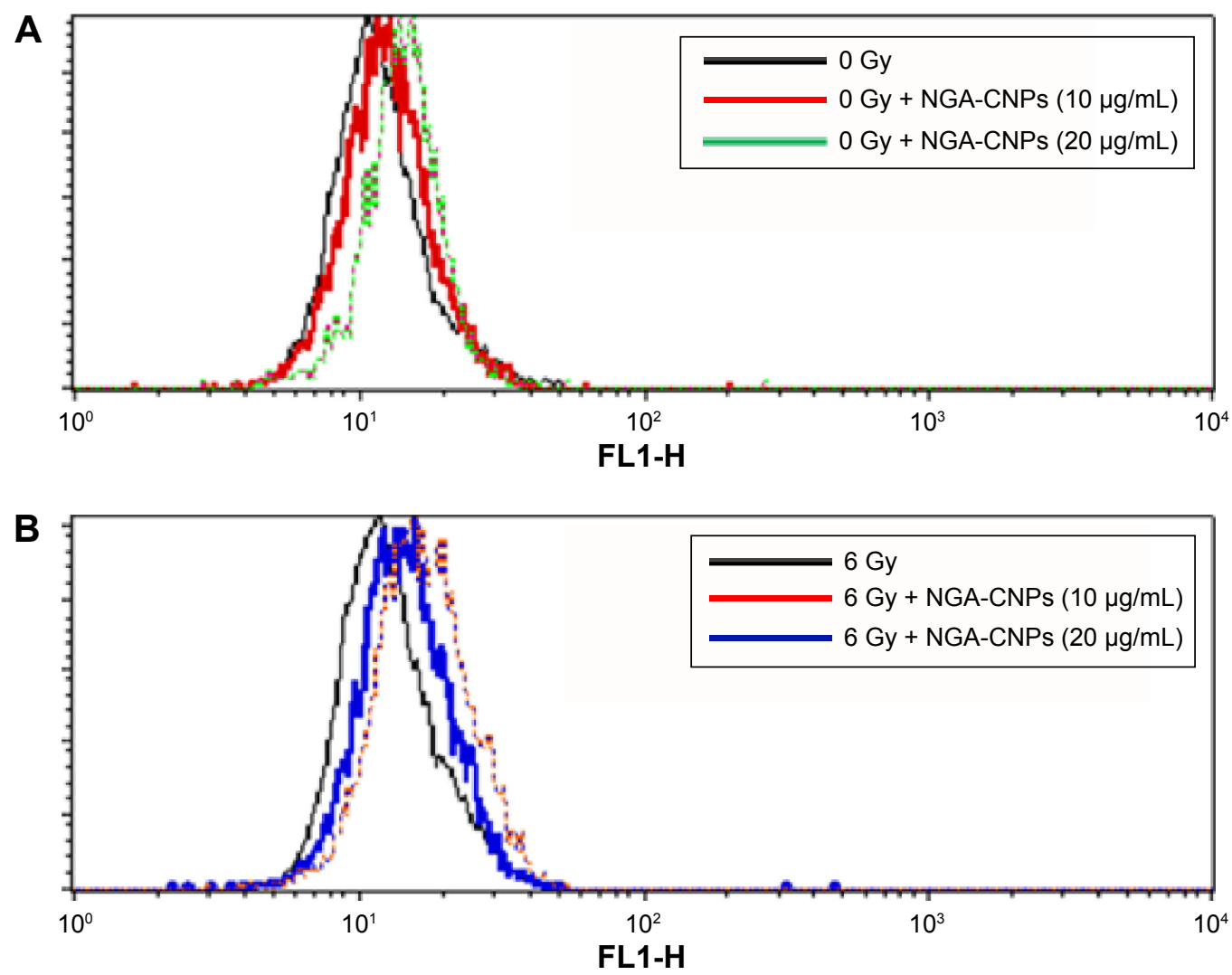

Figure 8 Detection of autophagy in MCF-7 cells by flow cytometry.

Notes: Cells were treated with indicated concentrations of NGA-CNPs without (A) or with (B) subsequent radiation treatment. A $488 \mathrm{~nm}$ laser source and the FLI channel were used to detect the green fluorescence of autophagic cells.

Abbreviation: NGA-CNP, ceria nanoparticle modified with neogambogic acid.

\section{NGA-CNPs suppress the generation of ROS}

Oxidative stress, which elicits major changes in cellular function such as the induction of antioxidant enzymes, cell cycle arrest, and apoptosis, is frequently the cause of radiation-induced toxicity. ${ }^{51}$ Radiation and gold and silver NPs have been shown to cause ROS-mediated cell death. ${ }^{52}$ Given that ROS can also induce autophagy, ${ }^{53}$ we investigated the changes in ROS levels resulting from combined NGA-CNP and radiation treatment with a fluorometric assay that detects intracellular oxidation of DCFH-DA by flow cytometry. DCFH-DA is hydrolyzed by esterases to DCFH, which remains trapped within the cell and is oxidized to the fluorescent molecule dichlorofluorescein (DCF) by the action of cellular oxidants; the detection of DCF provides an indication of intracellular ROS level.

NGA-CNP treatment inhibited endogenous and radiationinduced ROS formation (Figure 9A), in contrast with the reported effects of other nanomaterials. ${ }^{36}$ This may be explained by the oxygen vacancy sites on the surface of the nanoceria lattice, ${ }^{54}$ which have cerium (3+) atoms at the center surrounded by cerium (4+) atoms that can absorb ROS. ${ }^{55} \mathrm{Ce} 3 \mathrm{D}$ features collected for reference powders (NGA-CNPs) were investigated in order to determine the positions of various components and were deconvoluted using a peak-fitting process. The NGA-CNP spectrum was composed of two multiplets ( $u$ and $v$ ) corresponding to the spin-orbit split $3 \mathrm{~d}_{3 / 2}$ and $3 \mathrm{~d}_{3 / 5}$ core boles shown in Figure 9B. ${ }^{56}$ The spin-orbit splitting was approximately $18.6 \mathrm{eV}$, and the intensity ratio $I\left(3 \mathrm{~d}_{5 / 2}\right) / I\left(3 \mathrm{~d}_{3 / 2}\right)$ was fixed at $1.5 .{ }^{57}$ The highest binding energy peaks, $u^{\prime \prime \prime}$ and $v^{\prime \prime \prime}$ were located at around $916.9 \mathrm{eV}$ and $898.3 \mathrm{eV}$, respectively, while the satellite peaks $u^{\prime \prime \prime}$ and $v^{\prime \prime \prime}$ associated with Ce $3 \mathrm{~d}_{3 / 2}$ indicated the presence of $\mathrm{Ce}^{4+}$ and $\mathrm{Ce}^{3+}$, respectively, in NGA-CNPs. The lowest binding energy states $u, u^{\prime \prime}, v$, and $v^{\prime \prime}$ located at $901.3 \mathrm{eV}, 907.3 \mathrm{eV}, 882.7 \mathrm{eV}$, and $888.5 \pm 0.1 \mathrm{eV}$, respectively, were the result of Ce $3 d^{9} 4 f^{2} \mathrm{O} 2 \mathrm{p}^{4}$ and $\mathrm{Ce} 3 \mathrm{~d}^{9} 4 \mathrm{f}^{1}$ O $2 \mathrm{p}^{5}$ final states. ${ }^{58,59}$ These findings suggest that the NGACNP-induced sensitization of cancer cells to the effects of radiation is not achieved via the generation of ROS.

\section{Conclusion}

CNPs with sizes of 3-5 nm and modified with NGA were not toxic to breast cancer cells at concentrations of $10 \mu \mathrm{g} / \mathrm{mL}$ or $20 \mu \mathrm{g} / \mathrm{mL}$. However, when combined with radiation, 

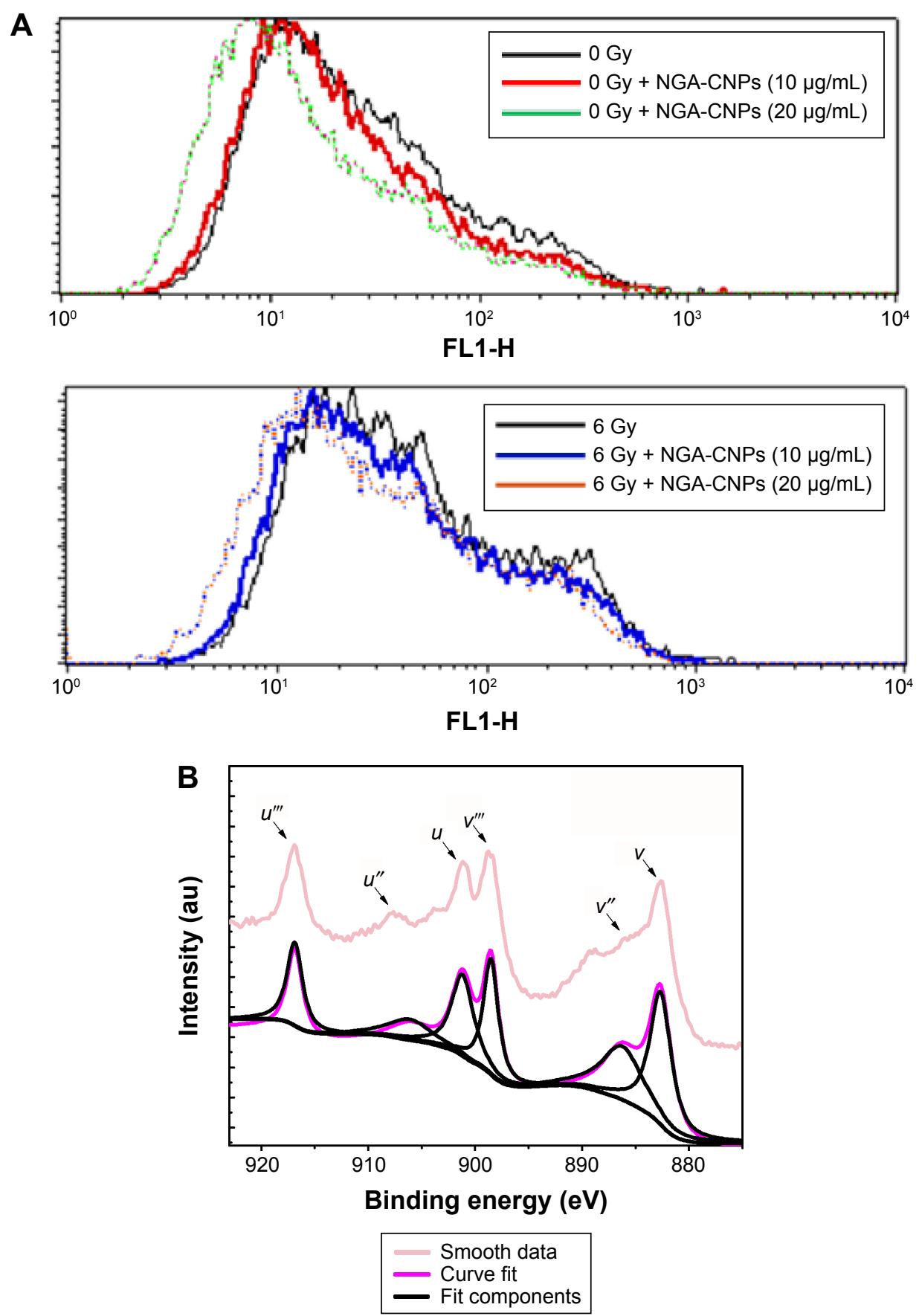

Figure 9 Detection of ROS in MCF-7 cells by flow cytometry.

Notes: (A) Suppression of ROS generation in MCF-7 cells by NGA-CNPs. Cells were treated with indicated concentrations of NGA-CNPs without (top) or with (bottom) subsequent radiation treatment. A fluorometric assay based on the oxidation of DCFH-DA by intracellular oxidants was used in conjunction with flow cytometry to detect ROS. (B) Ce $3 d_{3 / 2,5 / 2}$ XPS spectrum for NGA-CNPs.

Abbreviations: ROS, reactive oxygen species; NGA-CNP, ceria nanoparticle modified with neogambogic acid; DCFH-DA, 2',7'-dichlorofluorescin diacetate; XPS, X-ray photoelectron spectroscopy.

NGA-CNPs caused G2/M arrest, induced autophagy, and increased the rate of cell death as compared to NGA, CNPs, or radiation treatment alone. These findings suggest that NGACNPs can be used as an adjuvant treatment to increase cancer cell sensitivity to the toxic effects of radiation, which would lower the effective doses of radiation that are used and thereby reduce damage to healthy tissue surrounding the tumor site.

\section{Acknowledgments}

The study was supported by the National Key Basic Research Program of China (973 Program, grant number: 2013CB933904), the National Nature Science Foundation of China (grant number: 31400721), the Nature Science Foundation of Jiangsu Province (grant number: BK20131355), and the Priority Academic Program Development of Jiangsu 
Higher Education Institutions. The authors thank the College of Materials Science and Technology, Nanjing University of Aeronautics and Astronautics, and Jiangsu Laboratory for Biomaterials and Devices, Southeast University, for providing technical support for this research.

\section{Disclosure}

The authors report no conflicts of interest in this work.

\section{References}

1. Montazerabadi AR, Sazgarnia A, Bahreyni-Toosi MH, Ahmadi A, Aledavood A. The effects of combined treatment with ionizing radiation and indocyanine green-mediated photodynamic therapy on breast cancer cells. J Photochem Photobiol B Biol. 2012;109:42-49.

2. Xie Q, Zhou Y, Lan G, et al. Sensitization of cancer cells to radiation by selenadiazole derivatives by regulation of ROS-mediated DNA damage and ERK and AKT pathways. Biochem Biophys Res Commun. 2014;449(1):88-93.

3. Kawasaki ES, Player A. Nanotechnology, nanomedicine, and the development of a new, effective therapies for cancer. Nanomedicine. 2005; 1(2):101-109.

4. Shen J, Song G, An M, et al. The use of hollow mesoporous silica nanospheres to encapsulate bortezomib and improve efficacy for nonsmall cell lung cancer therapy. Biomaterials. 2014;35(1):316-326.

5. Eom HJ, Choi J. Oxidative stress of $\mathrm{CeO}_{2}$ nanoparticles via p38-Nrf-2 signaling pathway in human bronchial epithelial cell, Beas-2B. Toxicol Lett. 2009;187(2):77-83.

6. Xu C, Qu XG. Cerium oxide nanoparticle: a remarkably versatile rare earth nanomaterial for biological application. NPG Asia Mater. 2014;6:e90.

7. Hussain S, Al-Nsour F, Rice AB, et al. Cerium dioxide nanoparticles induce apoptosis and autophagy in human peripheral blood monocytes. ACS Nano. 2012;6(7):5809-5820.

8. Ciofani G, Genchi GG, Liakos I, et al. Effect of cerium oxide nanoparticles on PC12 neuronal-like cells: proliferation, differentiation, and dopamine secretion. Pharm Res. 2013;30(8):2133-2145.

9. Rocca A, Mattoli V, Mazzolai B, Ciofani G. Cerium oxide nanoparticles inhibit adipogenesis in rat mesenchymal stem cells: potential therapeutic implication. Pharm Res. 2014;31(11):2952-2962.

10. Walker C, Das S, Seal S, et al. Catalytic properties and biomedical applications of cerium oxide nanoparticles. Environ Sci Nano. 2015;2(1):33-53.

11. Colon J, Hsieh N, Ferguson A, et al. Cerium oxide nanoparticles protect gastrointestinal epithelium from radiation-induced damage by reduction of reactive oxygen species and upregulation of superoxide dismutase 2 . Nanomedicine. 2010;6(5):698-705.

12. Tarnuzzer RW, Colon J, Patil S, Seal S. Vacancy engineered ceria nanostructures for protection from radiation-induced cellular damage. Nano Lett. 2005;5(12):2573-2577.

13. Chaachouay H, Ohneseit P, Toulany M, Kehlbach R, Multhoff G, Rodemann HP. Autophagy contributes to resistance of tumor cells to ionizing radiation. Radiother Oncol. 2011;99(3):287-292.

14. Rabinowitz JD, White E. Autophagy and metabolism. Science. 2010; 330(6009):1344-1348.

15. Yuk JM, Shin DM, Song KS, et al. Bacillus calmette-guerin cell wall cytoskeleton enhances colon cancer radiosensitivity through autophagy. Autophagy. 2010;6(1):46-60.

16. Kim R, Emi M, Tanabe K, et al. The role of apoptosis or nonapoptosis cell death in determining cellular response to anticancer treatment. EJSO. 2006;32(3):369-377.

17. Mei W, Dong C, Hui C, et al. Gambogenic acid kills lung cancer cells through aberrant autophagy. PLoS One. 2014;9(1):e83604.

18. Zhou GZ, Zhang SN, Zhang L, Sun GC, Chen XB. A synthetic curcumin derivative hydrazinobenzoylcurcumin induces autophagy in A549 lung cancer cells. Pharm Biol. 2014;52(1):111-116.
19. Yan F, Wang M, Chen H, et al. Gambogenic acid mediated apoptosis through the mitochondrial oxidative stress inactivation of Akt signaling pathway in human nasopharyngeal carcinoma CNE-1 cell. Eur J Pharmacol. 2011;652(1-3):23-32.

20. Yu XJ, Han QB, Wen ZS, Ma L, Gao J, Zhou GB. Gambogenic acid induces G1 arrest via GSK3 $\beta$-dependent cyclin D1 degradation and triggers autophagy in lung cancer cells. Cancer Lett. 2012;322(2):185-194.

21. Zhou J, Luo YH, Wang JR. Gambogenic acid induction of apoptosis in a breast cancer cell line. Asian Pac J Cancer Prev. 2013;14(12): 7601-7605.

22. Patil S, Kuiry SC, Seal S, Vanfleet R. Synthesis of nanocrystalline ceria particles for high temperature oxidation resistant coating. J Nanopart Res. 2002;4(5):433-438.

23. Zhou XD, Huebner W, Anderson HU. Room-temperature homogeneous nucleation synthesis and thermal stability of nanometer single crystal $\mathrm{CeO}_{2}$. Appl Phys Lett. 2002;80(20):3814-3816.

24. Bumajdad A, Zaki MI, Eastoe J, Pasupulety L. Microemulsion-based synthesis of $\mathrm{CeO}_{2}$ powders with surface area and high-temperature stabilities. Langmuir. 2004;20(25):11223-11233.

25. Xue Y, Luan QF, Yang D, Yao X, Zhou KB. Direct evidence for hydroxyl radical scavenging activity of cerium oxide nanoparticles. JPhys Chem C. 2011;115(11):4433-4438

26. Barbara DA, Santucci S, Benedetti E, Di Loreto S, Phani AR, Falone S. Cerium oxide nanoparticles trigger neuronal survival in a human Alzheimer disease model by modulating BDNF pathway. Curr Nanosci. 2009;5(2):167-176.

27. Cimini A, D'Angelo B, Das S, et al. Antibody-conjugated PEGylated cerium oxide nanoparticles for specific targeting of A beta aggregates modulate neuronal survival pathways. Acta Biomater. 2012;8(6): 2056-2067.

28. Santos MJ, Quintanilla RA, Toro A, et al. Peroxisomal proliferation protects from beta-amyloid neurodegeneration. J Biol Chem. 2005; 280(49):41057-41068.

29. Patil S, Reshetnikov S, Haldar MK, et al. Surface-derivatized nanoceria with human carbonic anhydrase II inhibitors and fluorophores: a potential drug delivery device. J Phys Chem. 2007;111(24):8437-8442.

30. Sazgarnia A, Montazerabadi AR, Bahreyni-Toosi MH, Ahmadi A, Aledavood A. In vitro survival of MCF-7 breast cancer cells following combined treatment with ionizing radiation and mitoxantrone-mediated photodynamic therapy. Photodiagnosis Photodyn Ther. 2013;10(1):72-78.

31. Cui FB, Li RT, Liu Q, et al. Enhancement of radiotherapy efficacy by docetaxel-loaded gelatinase-stimuli PEG-Pep-PCL nanoparticles in gastric cancer. Cancer Lett. 2014;346(1):53-62.

32. Zhang XD, Wu D, Shen X, et al. Size-dependent radiosensitization of PEG-coated gold nanoparticles for cancer radiation therapy. Biomaterials. 2012;33(27):6408-6419.

33. Roa W, Zhang X, Guo L, et al. Gold nanoparticles sensitize radiotherapy of prostate cancer cells by regulation of the cell cycle. Nanotechnology. 2009;20(37):375101

34. Klionsky DJ, Abeliovich H, Agostinis P, et al. Guidelines for use and interpretation of assays for monitoring autophagy in higher eukaryotes. Autophagy. 2008;4(2):151-175.

35. Mizushima N, Yoshimori T, Levine B. Methods in mammalian autophagy research. Cell. 2010;140(3):313-326.

36. Kim S, Choi JE, Choi J, et al. Oxidative stress-dependent toxicity of silver nanoparticles in human hepatoma cells. Toxicol In Vitro. 2009; 23(6):1076-1084.

37. Harhaji L, Isakovic A, Raicevic N, et al. Multiple mechanisms underlying the anticancer action of nanocrystalline. J Appl Polymer Sci. 2007;568(1-3):89-98.

38. Kondo Y, Kanzawa T, Sawaya R, Kondo S. The role of autophagy in cancer development and response to therapy. Nat Rev Cancer. 2005; 5(9):726-734

39. Whiter E, DiPaola RS. The double-edged sword of autophagy modulation in cancer. Clin Cancer Res. 2009;15(17):5308-5316.

40. Amaravadi RK, Lippincott-Schwartz J, Yin XM, et al. Principles and current strategies for targeting autophagy for cancer treatment. Clin Cancer Res. 2011;17(4):654-666. 
41. Dalby KN, Tekedereli I, Lopez-Berestein G, Ozpolat B. Targeting the prodeath and prosurvival functions of autophagy as a novel therapeutic strategies in cancer. Autophagy. 2010;6(3):322-329.

42. Yang ZJ, Chee CE, Huang S, Sinicrope FA. The role of autophagy in cancer: therapeutic implications. Mol Cancer Ther. 2011;10(9): 1533-1541.

43. Ouyang L, Shi Z, Zhao S, et al. Programmed cell death pathways in cancer: a review of apoptosis, autophagy and programmed necrosis. Cell Prolif. 2012;45(6):487-498.

44. White E, Karp C, Strohecker AM, Guo Y, Mathew R. Role of autophagy in suppression of inflammation and cancer. Curr Opin Cell Biol. 2010;22(2):212-217.

45. Milani M, Rzymski T, Mellor HR, et al. The role of ATF4 stabilization and autophagy in resistance of breast cancer cells treated with Bortezomib. Cancer Res. 2009;69(10):4415-4423.

46. Chen N, Karantza V. Autophagy as a therapeutic target in cancer. Cancer Biol Ther. 2011;11(2):157-168.

47. Kim RH, Coates JM, Bowles TL, et al. Arginine deiminase as a novel therapy for prostate cancer induces autophagy and caspase-independent apoptosis. Cancer Res. 2009;69(2):700-708.

48. Dikic I, Johansen T, Kirkin V. Selective autophagy in cancer development and therapy. Cancer Res. 2010;70(9):3431-3434.

49. Shintani T, Klionsky DJ. Autophagy in health and disease: a doubleedged sword. Science. 2004;306(5698):990-995.

50. Zhang Y, Yu C, Huang G, Wang C, Wen L. Nano rare-earth oxides induced size-dependent vacuolization: an independent pathway from autophagy. Int J Nanomedicine. 2010;5:601-609.
51. Gao Z, Sarsour EH, Kalen AL, Li L, Kumar MG, Goswami PC. Late ROS accumulation and radiosensitivity in SOD1-overexpressing human glioma cells. Nanomed Nanotechnol Biol Med. 2013;9(4):558-569.

52. Shi JM, Bai LL, Zhang DM, et al. Saxifragifolin D induces the interplay between apoptosis and autophagy in breast cancer cells through ROD-dependent endoplasmic reticulum stress. Biochem Pharmacol. 2013;85(7):913-926.

53. Azad MB, Chen YQ, Gibson SB. Regulation of autophagy by reactive oxygen species (ROS): implication for cancer progression and treatment. Antioxid Redox Signal. 2009;11(4):777-790.

54. Sahu T, Bisht SM, Das RK, Kirit R. Nanoceria: synthesis and biomedical applications. Curr Nanosci. 2013;9(5):588-593.

55. Briggs A, Corde S, Oktaria S, et al. Cerium oxide nanoparticles: influence of the high-Z component revealed on radioresistant 9L cell survival under X-ray irradiation. Nanomedicine. 2013;9(7):1098-1105.

56. Beche E, Charvin P, Perarnau D, et al. Ce 3d XPS investigation of cerium oxides and mixed cerium $\left(\mathrm{Ce}_{\mathrm{x}} \mathrm{Ti}_{\mathrm{y}} \mathrm{O}_{\mathrm{z}}\right)$. Surf Interface Anal. 2008; 40(3-4):264-267.

57. Escamilla-Perea L, Nava R, Pawelec B, et al. SBA-15-supported gold nanoparticles decorated by $\mathrm{CeO}_{2}$ : structural characteristics and $\mathrm{CO}$ oxidation activity. Appl Catal A. 2010;381(1-2):42-53.

58. Tuller HL, Nowick AS. Defect structure and electrical properties of nonstoichiometric $\mathrm{CeO}_{2}$ single crystals. J Electrochem Soc. 1979; 126(2):209-217.

59. Boronin AI, Slavinskaya EM, Danilova IG, et al. Investigation of palladium interaction with cerium oxide and its state in catalysts for lowtemperature CO oxidation. Catal Today. 2009;144(3-4):201-211.
International Journal of Nanomedicine

\section{Publish your work in this journal}

The International Journal of Nanomedicine is an international, peerreviewed journal focusing on the application of nanotechnology in diagnostics, therapeutics, and drug delivery systems throughout the biomedical field. This journal is indexed on PubMed Central, MedLine, CAS, SciSearch $®$, Current Contents $\AA /$ Clinical Medicine,

\section{Dovepress}

Journal Citation Reports/Science Edition, EMBase, Scopus and the Elsevier Bibliographic databases. The manuscript management system is completely online and includes a very quick and fair peer-review system, which is all easy to use. Visit http://www.dovepress.com/ testimonials.php to read real quotes from published authors. 